\title{
The Power of Incumbency: Abdul Gani Kasuba's Strategy to Win the Voice of the Makean Ethnic Group in South Halmahera in the 2018 Noth Maluku Governor Election
}

\author{
Agusmawanda $^{1}$, La ode Muhmeliadi ${ }^{2}$, Mahmud Husen $^{3}$ \\ \{agusmawanda79@gmail.com ${ }^{1}$ \} \\ Departmen Political Science, Muhammadiyah University North Maluku ${ }^{1,2,3}$
}

\begin{abstract}
Sociological factors that base ethnic identity in each political context in the region, elections for governors, mayors, and regents have always been vital in political struggles at the electoral level. Likewise, in the political tradition in North Maluku Province, the ethnic sentiment is an instrument used to get electoral support. In the 2018 gubernatorial election in Kayoa District South Halmahera, ethnic instrumentation did not work because the incumbent Governor, who had a Tobelo-Galela ethnic background, managed to win votes. The Makean-Kayoa ethnic group surpassed the other candidates with the Makean-Kayoa ethnic background. Thus, the research question is how the incumbent Governor's political strategy won the Makean ethnic group's vote. This study uses qualitative methods, with data collection techniques through in-depth interviews by interviewers to respondents. The result found; Strategic Program Campaign, Utilizing AGK Popularity as Ulama, Party Machine Power, and Politics of the Kasuba Clan.
\end{abstract}

Keywords: Incumbent, political strategy, ethnic identity

\section{Introduction}

In general, the incumbent has its advantages in each political context because it has specific political resources that other candidates do not have. Kenichi Ariga's research shows how political parties benefit from obtaining votes at the local level by nominating incumbents [1]. Hans JG Hassell's research, how demographic factors such as race influence local voting behavior in America [2], Research from Todd K. Hartman, act., How local party competition in England responds to new information from survey results shows their racial superiority to allocating political resources [3]. Furthermore, Dalston G. Ward and Margit Tavits' research, how partisans influence perceptions of party ideology and political competition. [4].

Meanwhile, in Indonesia, the primordial aspect is the most significant political instrument to political mobilization [5]. With religion, the primordial element can also contribute to fragmentation in political parties, affecting the number of political parties' representatives at the regional level [6]. Other research shows that the clientelism aspect is more dominant than the ideological element in Indonesian society, which experienced ideological splits during the authoritarian period [7]. Research that focuses on political parties' strategy in legislative elections in West Sumatra, with findings; take advantage of party leaders' influence, socialization of candidates directly and in the media, and contributions [8]. Furthermore, 
Wahyudin and Sunarso's research, political strategy in the election of Mayor of Bima includes; Strategy Koalaisi party political, Team Building successful and Volunteers [9]

However, in the election for the Governor of North Maluku in Kayoa District, South Halmahera in 2018, the ethnicity factor did not matter because the incumbent Governor who had a Tobelo-Galela ethnic background won 1,653 votes over other candidates with the MakeanKayoa ethnic background (Table.1). Therefore, this study aims to determine the political strategy of the incumbent Governor in winning the election in Koyoa District, Halmaheras Selatan. Therefore, this research seeks to explain the incumbent Governor's political strategies in winning the election in Koyoa District, South Halmahera.

Table.1 Number of votes and Candidate Status

\begin{tabular}{lllcc}
\hline \multicolumn{1}{c}{ Candidate } & \multicolumn{1}{c}{ Base Etnic } & \multicolumn{1}{c}{ Status } & Number of Votes & $\%$ \\
\hline AHM-RIVAI & Lain-Makean/Kayoa & Challeger & 1267 & 31,24 \\
BUR-JADI & Lain-lain & Challeger & 744 & 18,34 \\
AGK-YA & Tobelo/Galela-lain & Incumbent & 1653 & 40,75 \\
MK-MAJU & Tobelo/Galela-lain & Challeger & 392 & 9,66 \\
\hline \multicolumn{1}{c}{ Total } & & & 4056 & 100 \\
\hline
\end{tabular}

Sources: https://malut.kpu.go.id

\section{Method}

The word strategy comes from "strategos," the Ancient Greek which is defined as a "team leader," so in this case, the strategic means the art of being a commander in the war to formulate battle formations to achieve victory [10]. Political strategy is a strategy used to realize political ideals such as enacting new regulations, filling or replacing new structures in government, and others [11].

Further methods and locations conducted this research in Kayoa District, South Halmahera Regency. This study uses qualitative methods, with data collection techniques through in-depth interviews by interviewers to respondents [12] consisting of; Abdul Gani Kasuba's winning team in Kayoa District, community leaders, and voters Makean-Kayoa Ethnic background. The available data are then grouped based on the data's similarity and analyzed in the form of a narrative to obtain conclusions [13].

\section{Results and Discussion}

In every general election, whether the election of a president or regional heads (governors, regents, or mayors), identity politics often colors public discourse. In the local political context, ethnic identity is in an important position, as was the case with the Governor of North Maluku for 2018-2023 in Kayoa Halmahera Selatan District. Kayoa District is the majority of the Makean-Kayoa ethnic group. Abdul Gani Kasuba and M. Al Yasin Ali (AGK-YA) use political strategies to win the team Strategic Program Campaign, Utilizing AGK Reputation as Ulama, Party Machine Power, and Politics of the Kasuba Clan (Figure 1). 


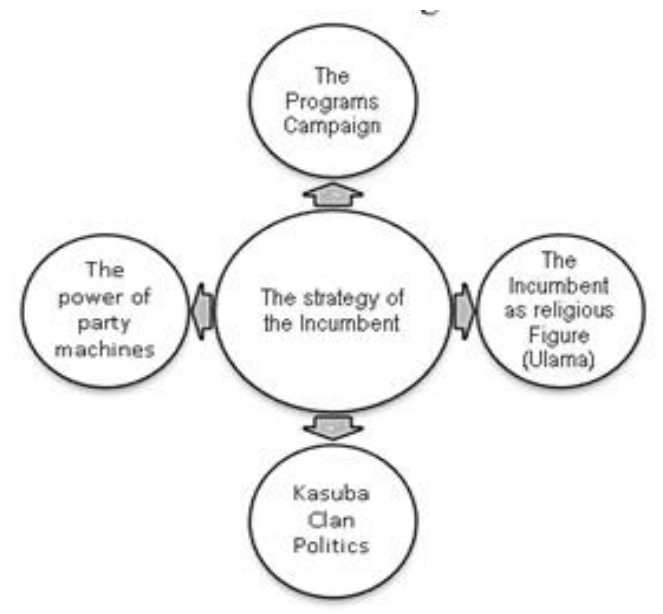

Fig. 1. Political Strategies

The first strategy is the program campaign. Couple Abdul Gani Kasuba and M. Al Yasin Ali (AGK-YA), where AGK as a campaigner, conducted a strategic program campaign during his tenure as Governor of North Maluku Province 2013-2018. He is committed in the coming period if he is elected, then will improve and enhance existing programs such as; programs in education and health, infrastructure, attention to border areas, economics, and governance. So AGK-YA partner, leveraging strategic program AGK during his tenure as Governor of North Maluku, as a campaign to influence the trend in ethnic make-Kayoa in North Maluku governor's election in 2018.

The second strategy is to take advantage of the popularity of AGK as a religious figure. Before AGK entered as a politician by being the Deputy Governor of two terms and became the Governor of North Maluku, he had traveled throughout North Maluku as a Dai and teacher. He was known and had many disciples. Therefore, the campaign team utilized that popularity as a selling point to voters in Kayoa so that voters with a high religiosity level will choose the AGKYA partner.

The Third strategy is the power of party machines. The AGK-YA pair utilizes the Indonesian Democratic Party of Struggle Party (PDIP) machine as a large party that has a network from the center to the village level. The PDIP has a vital party institution to quickly mobilize cadres and party sympathizers to gain support for the Makean-Kayoa ethnic group, even though the AGK-YA pair comes from the Tobelo-Galela ethnic group.

The fourth strategy is Kasuba Clan Politics. In South Halmahera Regency, where the Kayoa subdistrict being, the Regent is led by the same clan as AGK. Thus, assumed that the victory of AGK-YA in the election of the Governor of North Maluku 2018 will benefit South Halmahera's people because the Regent can communicate easily with the Governor both structurally and as a family because they are still in close family ties. Thus, the campaign team informed voters that winning the AGK-YA would facilitate policy synchronization between South Halmahera and North Maluku Province.

Furthermore, this study's findings are that the instrumentation of ethnic identity is not related to candidates' vote acquisition because the incumbent with a Tobelo-Galela ethnic background managed to win over other candidates with a Makean-Kayoa ethnic background in the Makean-Kayoa constituency. Based on these findings, the Makean-Kayoa ethnic group's 
characteristics in the 2018 North Maluku governor election were rational voters. As rational voters, the Makean-Kayoa ethnic group chose the Incumbent candidate because they considered that the incumbent had successfully carried out basic service programs, such as; education, health, infrastructure, and economic agenda. Thus, the strategy of campaigning for the governor's plan is very beneficial for the incumbent and has been proven to influence the voting behavior of the Makean-Kayoa ethnic group in South Halmahera.

Another argument why the ethnic identity instrumentation does not work in the MakeanKayoa community in South Halmahera is the popularity of the Incumbent as a religious figure in North Maluku. Long before Abdul Gani Kasuba became political by becoming deputy governor for two terms and becoming governor of North Maluku for the 2014-2018 period, he was known as the Ulama or religious figure in North Maluku. While on the other hand, the Makean-Kayoa ethnic group is an ethnic group that is also religious and will consider this aspect in determining their choice. So, Abdul Gani Kasuba's position as an incumbent with several strategic programs during his tenure as governor and as an Ulama weakened the Makean-Kayoa community's instrument.

As a result of this research, in a political context involving the incumbent, ethnic identity does not influence voting conduct at the local level, and it also confirms the discrepancies in conclusions with previous studies such as; Hassell [2], Hartman [3], and Agusmawanda [5], those who find that ethnic and racial identity are the primary tools for political mobilization at the local level because the sociological aspect of the candidate does not affect, theoretically, the psychological part of the candidate's figure and the rational aspect of the success of the current program while serving as governor.

\section{Conclusion}

Based on the research findings, the incumbent's political strategy in obtaining a majority vote in the Makean-Kayoa ethnic group in Kayoa District, South Halmahera, namely, Strategic Program Campaign, Using AGK's Popularity as Ulama, the Power of the Party Machine and the Politics of the Kasuba Clan. Furthermore, another finding in this study is that the ethnic identity factor has no effect on political expectations at the local level, where incumbents who have successfully run the program during their tenure as governor are also known as religious leaders in society.

\section{References}

[1] Kenichi Ariga.2020. When do political parties benefit from incumbents' personal votes? Comparative analysis across different electoral systems, Electoral Studies, Volume 68,2020,102221, ISSN 0261-3794, https://doi.org/10.1016/j.electstud.2020.102221.

[2] Hans J.G. Hassell. 2020. Local racial context, campaign messaging, and public political behavior: A congressional campaign field experiment, Electoral Studies, Volume 69,2021,102247, ISSN 0261-3794, https://doi.org/10.1016/j.electstud.2020.102247.

[3] Todd K. Hartman, Charles Pattie, Ron Johnston. 2017.Learning on the job? Adapting party campaign strategy to changing information on the local political context, Electoral Studies,


https://doi.org/10.1016/j.electstud.2017.06.005. 
[4] Dalston G. Ward, Margit Tavits.2019. How partisan affect shapes citizens' perception of the political world, Electoral Studies, Volume 60, 2019,102045, ISSN 0261-3794, https://doi.org/10.1016/j.electstud.2019.04.009.

[5] Agusmawanda. 2018. Political Primordialism on Local Election In Indonesia International Journal Of Scientific \& Technology Research Volume 7, Issue 7, July 2018. https://www.ijstr.org/final-print/july2018/Political-Primordialism-On-Local-Election-InIndonesia.pdf.

[6] Blane D. Lewis.2018. Endogenous district magnitude and political party fragmentation in subnational Indonesia: A research note, Electoral Studies, Volume 55, 2018, Pages 136145, ISSN 0261-3794, https://doi.org/10.1016/j.electstud.2018.06.005.

[7] Diego Fossati, Edward Aspinall, Burhanuddin Muhtadi, Eve Warburton.2020.Ideological representation in clientelistic democracies: The Indonesian case, Electoral Studies, $\begin{array}{llll}\text { Volume } & 63, & 2020,102111, & \text { ISSN }\end{array}$ https://doi.org/10.1016/j.electstud.2019.102111.

[8] Atri Waldi, Miyato, Maria Montessori, Engkizar. 2018. The Strategy of Political Parties in Wining Legislative Elections in Indonesia: Studies in Dharmasyara District. International Journal of Multidisciplinary of Higher Education Volume 1, Number 1, October 2018.

[9] Wahyudin \& Sunarso. 2020. The Strategies of Winning of Muhammad Lutfi Feri-Sofiyan in The 2018 Election in Bima City. Jurnal Studi Pemerintahan. 11(1). 4262. https://doi.org/10.18196/jgp.111111

[10] Robert Greene.2007. 33 Strategi Perang. Tangerang Karisma Publising Group. Edisi Terjemahan dari judul "The 33 Strategies War" oleh Editor Sigit Suryanto \& Lyndon Saputra

[11] Peter Schroder.2009. Strategi Politik, edisi revisi untuk pemilu 2009. Jakarta FriedrichNaumann-Stiftung Fur Die Freiheit, Indonesia. 2009.

[12] W Lawrence Neuman.2003. Social Research Methods: Qualitative And Quantitative Approaches Fifth Edition.Boston-New York, Pearson Education, Inc.

[13] Earl Babbie. 2008. The Basics of Social Research, Fourth Edition Thomson Wadsworth, 2008 